\title{
コンニャク葉枯病細菌の罹病小葉残渣，球茎および 土㙴における生存
}

\author{
林 宣夫* \\ Nobuo Hayashi*: Survival of Pseudomonas pseudoalcaligenes subsp. konjaci, the Causal \\ Agent of Bacterial Leaf Blight of Konnyaku (Amorphophallus konjac), \\ in Residues of Diseased Leaflets, on Corms and in Soil
}

\begin{abstract}
The investigation was conducted to make clear the infection sources of the bacterial leaf blight of konnyaku (Amorphophallus konjac) caused by Pseudonomas pseudoalcaligenes subsp. konjaci. Survival of the pathogenic bacterium in the diseased leaflets, on corms and in soil was determined by using a selective medium. The bacterium could be isolated from the diseased leaflets kept for 422 days on the soil surface of natural field, but not be isolated 106 days after the leaflets were buried at a depth of $5 \mathrm{~cm}$ in field soil. As the result of application of debris of the diseased leaflets onto soil surface of field immediately after planting corms, the disease occurred obviously on new leaflets grown from corms planted. When artificially infested corms were preserved at $10 \mathrm{C}$ of room temperature or in natural field soil, the bacterium could be recovered until 150 days after, namely until Apr. 14 in next spring. Survival of the bacterium in soil was longer at $5 \mathrm{C}$ than at $25 \mathrm{C}$, but the bacterium could not be detected after 60 days at $5 \mathrm{C}$ in natural field. These results indicate that the residues of diseased leaflets and corms infested with this bacterium may be served as main infection sources of the next konnyaku cultivation.
\end{abstract}

(Received June 12, 1989)

Key words: Pseudomonas pseudoalcaligenes subsp. konjaci, bacterial leaf blight of konnyaku, infection source, selective medium.

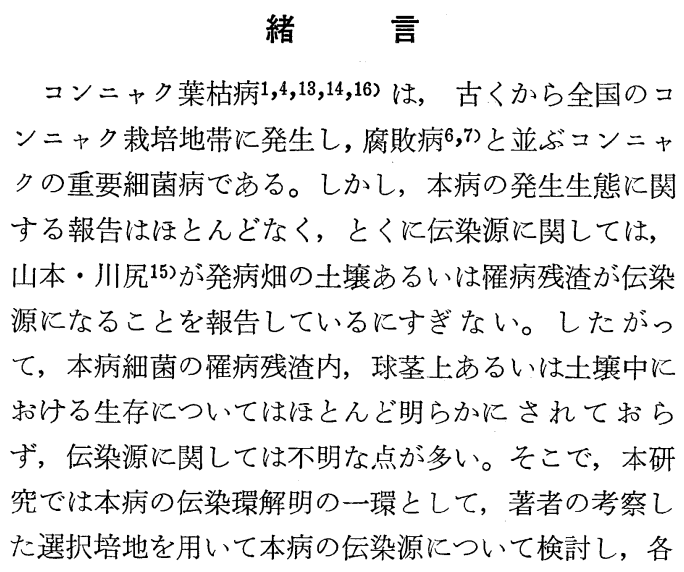

種条件下に拈ける本病細菌の生存期間を明らかにし た。

\section{材料および方法}

供試菌株 各実験とも, コンニ ク葉枯病細菌 Pseudomonas pseudoalcaligenes subsp. konjaci 4$)$ のス トレプトマイシン耐性変異株 7901-400 (群馬県農業総 合試験場保存菌株）を供した。供試細菌は, PPGA8) 斜面培地で $28 \mathrm{C}, 48$ 時間培養後, 所定濃度の懸濁液 に調製して実験に用いた。

実験場所 実験はいずれも群馬県前橋市の農業総合 試験場内で行った。

罹病小葉組織内における葉枯病細菌の生存期間 ポ

* 群馬県庁 Gunma Prefectural Office, Maebashi, Gunma 371, Japan 
ット栽培したコンニャク（品種・はるなくろ）の小葉 に $10^{7}$ colony forming units (cfu) $/ \mathrm{ml}$ の供試細菌を噴 霧接種し, 病斑形成後に病斑を含む数片の小葉を生重 量で約 $0.5 \mathrm{~g}$ 切り取り, $13 \times 18 \mathrm{~cm}$ のナイロンゴース の網袋に入れて，1 区当り 13 袋の罹病小葉入り網袋 を処理に供した。処理区は，1）殺菌土壌埋没区，2) 非殺菌土壤埋没区，3）非殺菌土壤地表面放置区，4） 実験室内放置区の 4 区とし，土壤埋没区での試料 は，供試土壤を $1 / 2,000 \mathrm{a}$ ポットに入れ深さ $5 \mathrm{~cm}$ の 位置に埋没した。処理後ポットは屋外の自然条件下で 管理した。な拉，殺菌土壤はクロルピクリン $80 \%$ 油 剂で土壤消毒して作成した。処理は 1984 年 9 月 11 日に行い, 処理後, 経時的に各処理区からナイロンゴ 一スの網袋を 1 袋ずつ取り出し, 罹病小葉の形状, 組 織の腐朽の程度を観察するとともに, 生存本病細菌数 を定量した。

罹病小葉残渣の圃場接種と発病 前項と同様に作成 した罹病小葉を $30 \times 40 \mathrm{~cm}$ のナイロンゴースの網袋 に入れ，1987 年 12 月 21 日から 1988 年 5 月 19 日まで固場の地表面に放置した。そして，1988 年 5 月 19 日にコンニャク栽培歴のない固場の $12 \mathrm{~m}^{2}(3 \times$ $4 \mathrm{~m}$ ) に 150 個のコンニャク種球（品種・はるなくろ, 2 年生) を植光付け, 覆土直後に試験区の中央部分の 地表面に上記罹病小葉残渣 $140 \mathrm{~g}$ を接種した。また, 対照として無接種区を設けた。な拈，作成した罹病小 葉残渣からは, 生重量 $1 \mathrm{~g}$ 当り $2.4 \times 10^{5} \mathrm{cfu}$ の本病細 菌が検出された。発病調査はコンニャクの小葉が展開 した後に，定期的に全株について行った。

コンニャク球茎上における葉枯病細菌の生存期間 1985 年 11 月 14 日に, コンニャク (品種・はるなく 万, 2 年生) の約 $50 \mathrm{~g}$ の球茎を約 $10^{7} \mathrm{cfu} / \mathrm{ml}$ の本病 細菌液に室温で 1 時間浸漬し, 風乾後実験に供した。 処理区は 1) $10 \mathrm{C}$ のコンニャク種球専用貯蔵庫内1 区，2）25 C の実験室内区，3）屋外地表放置区，4） 屋外土壌埋没区とした。な拉，1 区当り 16 個の球茎 を処理に供した。屋外に設置した区は，いずれも土壤

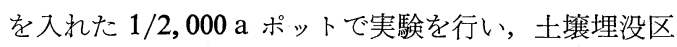
は深さ $10 \mathrm{~cm}$ の位置に供試球茎を埋没した。その後, 経時的に各処理区から球茎を 1 個ずつ取り出して, 主 芽の 伸長や 球茎表面の 腐敗の状況を調査するととも に, 生存本病細菌数を定量した。

また，各処理区から採種した球茎を 1986 年 5 月 10 日に高圧蒸気殺菌した土壤に植光付け, 小葉が展 開した後の 8 月 28 日に発病の有無を調査した。

土壤灌注した葉枯病細菌の生存期間 非殺菌土壤と
高圧蒸気殺菌土壤に供試細菌を灌注接種して, 乾土 1 $\mathrm{g}$ 当り約 $10^{6} \mathrm{cfu}$ の本病細菌を含む污染土塞を作成し, $200 \mathrm{ml}$ 容三角フラスコに $120 \mathrm{~g}$ ずつ入れた。これら を, $5 \mathrm{C}$ 拈よび $25 \mathrm{C}$ の定温器内に 1 区当り 12 本保 存し, 経時的にフラスコを 1 本ずつ取り出して土壤中 の生存本病細菌数を定量した。な扔, 実験開始時に打 ける污染土堙の含水比は約 $27 \%$ であった。

葉枯病細菌数の定量 羅病小葉組織内の生存本病細 菌数の定量は, ナイロンゴースの網袋の罹病小葉 約 $0.5 \mathrm{~g}$ を殺菌乳鉢に入れ, $10 \mathrm{ml}$ の殺菌水を用いて磨 砕し, 希釈原液之した。球茎上の生存本病細菌数の定 量は，球茎の皮をむき，その皮を $300 \mathrm{ml}$ 容三角フラ スコ中の $50 \mathrm{ml}$ の殺菌水に入れて 10 分間振とうし, 5 分間静置後, 上澄液を希釈原液とした。土堙中の生 存本病細菌数の定量は, 土壤 $5 \mathrm{~g} を 300 \mathrm{ml}$ 容三角フ ラスコ中の $45 \mathrm{ml}$ の殺菌水に入れて, 10 分間振とう したのち，5分間静置し，その上澄液を希釈原液とし た。いずれの場合でも, 分離用培地にはストレプトマ イシン $400 \mu \mathrm{g} / \mathrm{ml}$ 加用葉枯病細菌検出用選択培地 5 ) 用いた。この培地を平板とし, 各希釈原液の段階希釈 液 $0.1 \mathrm{ml}$ をコンラージ棒を用いて, ターンテーブル上 で全面に塗抹した。28 C，5 日間培養後出現した本病 細菌のコロニーを計数した。な打, 本病原細菌と酷似 したコロニーの一部をPPGA 斜面培地に移植・培養 後, ポット栽培したコンニャクの小葉に針接種して, 病原性を確認した。

\section{結果}

\section{罹病小葉組織内における葉枯病細菌の生存期間}

各処理区の罹病小葉の状態を各調查時期に観察した 結果, 非殺菌土壤埋没区は, 処理後 21 日で、小葉の 葉肉部分が 3 分の 1 程度腐朽し脱落した。処理 後 106 日では, 葉肉部分はほとんど消失し, 葉脈だけが 網目状に残った。しかし, 殺菌土壤中埋没区は, 処理 後 135 日でも小葉の大部分が処理時の形状を保って 抢り, また, 非殺菌土壤地表面放置区も, 処理後 330 日でも, 小葉の形状が確認できた。また, 実験室内放 置区は, 処理後 330 日でも完全に小葉の形を保って 㧍り, 病斑部も識別できた。

罹病小葉組織内の生存本病細菌数を経時的飞調查し た結果をTable 1 亿示した。本病細菌の生存期間は, 非殺菌土壌埋没区がもっとも短く, 処理後 106 日以降 検出できなかった。そ机に対し, 殺菌土塞埋没区は, 処理後 244 日でも検出できた。しかし, 処理後 330 日以降では検出できなかった。一方, 非殺菌土塞地表 
Table 1. Survival of Pseudomonas pseudoalcaligenes subsp. konjaci in diseased konnyaku leaflets kept under four different conditions

\begin{tabular}{|c|c|c|c|c|c|}
\hline \multirow{2}{*}{$\begin{array}{c}\text { Date of } \\
\text { measurement }\end{array}$} & \multirow{2}{*}{$\begin{array}{l}\text { Days after } \\
\text { treatment }\end{array}$} & \multicolumn{2}{|c|}{ Buried into a) } & \multirow{2}{*}{$\begin{array}{c}\text { Put onto surface } \\
\text { of nonsterilized } \\
\text { soil }\end{array}$} & \multirow{2}{*}{$\begin{array}{l}\text { In laboratory } \\
\text { room }\end{array}$} \\
\hline & & $\begin{array}{l}\text { sterilized } \\
\text { soil }\end{array}$ & $\begin{array}{l}\text { nonsterilized } \\
\text { soil }\end{array}$ & & \\
\hline Sept. 11,1984 & 0 & $7,570.00 \mathrm{~b})$ & $7,570.00$ & $7,570.00$ & $7,570.00$ \\
\hline Oct. $\quad 2,1984$ & 21 & 334.00 & $4,040.00$ & $1,080.00$ & 96.90 \\
\hline Dec. 26,1984 & 106 & 3.58 & $\left.\mathrm{ND}^{\mathrm{c}}\right)$ & 22.80 & $1,070.00$ \\
\hline Jan. 24,1985 & 135 & 17.90 & ND & 178.00 & 113.00 \\
\hline Mar. 30, 1985 & 200 & 0.46 & ND & 221.00 & 105.00 \\
\hline May 13,1985 & 244 & 0.22 & ND & 56.50 & 0.41 \\
\hline Aug. $\quad 7,1985$ & 330 & ND & ND & 1.85 & 0.02 \\
\hline Nov. 7,1985 & 422 & ND & ND & 1.00 & 0.11 \\
\hline Jan. 29,1986 & 505 & ND & ND & ND & ND \\
\hline
\end{tabular}

a) Diseased konnyaku leaflets were buried at a depth of $5 \mathrm{~cm}$ in soil.

b) Number of colony forming units (cfu) per $1 \mathrm{~g}$ of samples $\left(\times 10^{5}\right)$.

c) Not detected.

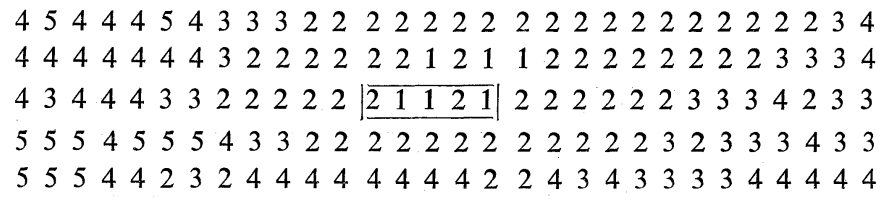

Fig. 1. Effect of residues of diseased konnyaku leaflet (infection source) on the occurrence of bacterial leaf blight. Infection source was prepared by leaving the diseased leaflets on soil surface of field from Dec. 21, 1987 to May 19, 1988. Then, it was applied to the soil surface of center area marked with $(\square)$ at immediately after planting of konnyaku corms. Numbers of 1, 2, 3, 4 and 5 in the figure show the dates of disease occurrence, and represent 1: Aug. 19, 2: Aug. 30, 3: Sept. 5, 4: Sept. 13 and 5: Sept. 28, respectively.

面放置区は，処理後 200 日でも罹病小葉 $1 \mathrm{~g}$ 当り $2.2 \times 10^{7} \mathrm{cfu}$ の本病細菌が検出され，その後，菌数は 減少したものの処理後 422 日まで生存が確認できた。 また，実験室内放置区に和いても 422 日まで生存が 確認された。

\section{罹病小葉残渣の固場接種亡発病}

コンニャク栽培歴のない直場の地表面に罹病小葉残 渣を接種した結果を Fig. 1 亿示した。

罹病小葉残渣無接種区ではまったく発病が認められ なかったが，接種区では罹病小葉残渣を接種した場所 およびその隣接部のコンニャクに植付け後 92 日に 発病が認められ，その後，それら発病株を中心に発生 が周囲へと拡大した。

\section{コンニャク球茎上における葉枯病細菌の生存期間}

各処理区に括けるコンニャク球茎の状態を調査した 結果, $10 \mathrm{C}$ のコンニャク種球専用貯蔵庫内区の球茎 は, 処理後, 150 日まで主芽の伸長や球茎表面の腐敗等
がなく貯蔵開始時と同様な状態にあった。25 C の実 験室区内の場合は主芽の伸長が認められ, 球茎が乾 燥しやや小さくなった。屋外地表面放置区の球茎は, 処理後 34 日の時点で表面が凍害により軟化し, 処理 後 150 日では球茎全体が 軟化腐敗した。屋外土埪埋 没区の球茎は，一部に軟化腐敗したものもあったが, 大部分が処理後 150 日まで処理開始時のものと同様 な状態にあった。

次に, 各処理区から採取した球茎上の生存本病細菌 数を経時的に調查した結果を Table 2 と示した。10 C コンニャク種球専用貯蔵庫内区と屋外土壤埋没区で は, 接種後 150 日でも $10^{3} \sim 10^{4} \mathrm{cfu}$ の本病細菌が検出 された。一方, $25 \mathrm{C}$ の実験室内区抢よび屋外地表面放 置区は，接種後 76 日まで生存が確認されたが，150日 後には検出できなくなった。

屋外地表面放置区を除く各処理区から採取した球茎 を殺菌土壤に植え付け，その後に展開した小葉に和け 
Table 2. Survival of Pseudomonas pseudoalcaligenes subsp. konjaci on artificially infested konnyaku corms kept under four different conditions

\begin{tabular}{|c|c|c|c|c|c|}
\hline \multirow{2}{*}{$\begin{array}{c}\text { Date of } \\
\text { measurement }\end{array}$} & \multirow{2}{*}{$\begin{array}{l}\text { Days after } \\
\text { treatment }\end{array}$} & \multicolumn{2}{|c|}{ Room temperature at } & \multicolumn{2}{|c|}{ Natural field soil } \\
\hline & & $10 \mathrm{C}$ & $25 \mathrm{C}$ & on surface & in soil a) \\
\hline Nov. 14,1985 & 0 & $46,156 \mathrm{~b})$ & 46,156 & 46,156 & 46,156 \\
\hline Dec. 18,1985 & 34 & 4,320 & 1,800 & 1,103 & 14,800 \\
\hline Jan. 29,1986 & 76 & 326 & 80 & 207 & 295 \\
\hline Apr. 14, 1986 & 150 & 18 & $\mathrm{ND}^{\mathrm{c})}$ & ND & 250 \\
\hline
\end{tabular}

a) Konnyaku corms were buried at a depth of $10 \mathrm{~cm}$ in soil.

b) Number of colony forming units (cfu) per the peel of about $50 \mathrm{~g}$ weight corm $\left(\times 10^{2}\right)$.

c) Not detected.

Table 3. Disease occurrence in konnyaku leaflets grown from artificially infested corms preserved under different conditions

\begin{tabular}{lcc}
\hline $\begin{array}{l}\text { Konnyaku corms a) } \\
\text { preserved at }\end{array}$ & $\begin{array}{c}\text { No. of corms } \\
\text { planted }\end{array}$ & $\begin{array}{c}\text { No. of diseased } \\
\text { plants }\end{array}$ \\
\hline $10 \mathrm{C}$ in room & 11 & 5 \\
$25 \mathrm{C}$ in room & 12 & 0 \\
Soil surface of natural field & $0 \mathrm{~b})$ & 3 \\
In natural field soil ${ }^{\mathrm{c}}$ ) & 5 & 3 \\
\hline
\end{tabular}

a) Corms were inoculated by soaking in the bacterial suspension and preserved under four different conditions from Nov. 14, 1985 to May 10, 1986. After that, they were planted to the sterilized soil on May 10, 1986, and the disease occurrence of konnyaku leaflets was observed on Aug. 28, 1986.

b) All corms were died during the preservation.

c) At a depth of $10 \mathrm{~cm}$.

Table 4. Survival of Pseudomonas pseudoalcaligenes subsp. konjaci in artificially infested soil

\begin{tabular}{|c|c|c|c|c|c|}
\hline \multirow{2}{*}{$\begin{array}{c}\text { Date of } \\
\text { measurement }\end{array}$} & \multirow{2}{*}{$\begin{array}{c}\text { Days after } \\
\text { treatment }\end{array}$} & \multicolumn{2}{|c|}{ In sterilized soil } & \multicolumn{2}{|c|}{ In nonsterilized soil } \\
\hline & & $5($ a) & $25 \mathrm{C}$ & $5 C$ & $25 \mathrm{C}$ \\
\hline Nov. 21,1987 & 0 & $\left.8.83 \times 10^{6} b\right)$ & $8.83 \times 10^{6}$ & $6.49 \times 10^{6}$ & $6.49 \times 10^{6}$ \\
\hline Dec. $\quad 1,1987$ & 10 & $7.85 \times 10^{6}$ & $3.47 \times 10^{7}$ & $1.88 \times 10^{6}$ & $7.57 \times 10^{5}$ \\
\hline Dec. 19, 1987 & 28 & 4. $58 \times 10^{5}$ & $3.38 \times 10^{5}$ & $2.03 \times 10^{3}$ & $\mathrm{ND}^{\mathrm{c}}$ ) \\
\hline Jan. $\quad 20,1988$ & 60 & $3.06 \times 10^{4}$ & $1.76 \times 10^{3}$ & ND & ND \\
\hline Mar. 18, 1988 & 118 & $9.72 \times 10^{3}$ & $2.70 \times 10^{2}$ & ND & ND \\
\hline Apr. 23, 1988 & 136 & $5.57 \times 10^{3}$ & ND & ND & ND \\
\hline
\end{tabular}

a) Soil temperature.

b) Number of colony forming units (cfu) per $1 \mathrm{~g}$ of dry soil.

c) Not detected.

る発病の有無を調查した結果をTable 3 に示した。 発病は $10 \mathrm{C}$ のコンニャク種球専用貯蔵庫内区括よ び屋外土壤埋没区の球茎で認められ，25 C の実験室 内区の球茎ではまったく発病が認められなかった。な 拈，屋外地表面放置区の球茎は軟化腐敗したため，植 付けできなかった。

\section{土畩灌注した葉枯病細菌の生存期間}

土壤に灌注した本病細菌の生存菌数を経時的に調査
した結果を Table 4 に示した。

殺菌土壌に灌注し，その後 5 C に保った場合は, 灌注後 136 日でも乾土 $1 \mathrm{~g}$ 当り $5.5 \times 10^{3} \mathrm{cfu}$ の本病 細菌が検出されたが，非殺菌土壌の場合は灌注後 60 日で検出されなくなった。また，25 C の場合は殺菌 土㖶, 非殺菌土㖶とも $5 \mathrm{C}$ に比べ生存期間が短く, 非殺菌土壌では灌注後 28 日で生存菌は検出できなか った。 


\section{考察}

コンニャク葉枯病の伝染源に関して, 污染土壌を付 着させた種球や，罹病小葉を埋没した土懔に植え付け た種球での発病が報告されている15)。しかし, 本病細 菌の各種条件下に拉ける生存期間については明らかに されていない。そこで本研究では, 本病の伝染源につ いて検討を行い, 眇病小葉残渣内, 球茎上拈よび土壤 中に打ける本病細菌の生存期間を明らかにした。

本病の罹病小葉を各種条件下で処理し, 経時的に本 病細菌の生存菌数を調査した結果, 非殺菌土壤に埋没 した場合は処理後約 3 カ月で検出されなかった。それ に対して, 殺菌土䁃に埋没した場合には処理後約 8 カ 月，非殺菌土壤の表面および実験室内に放置した場合 には約 14 力月後でも本病細菌の生存が確認された。 また，地表面に放置された罹病小葉残渣を植付け直 後のコンニャク圃場の地表面に接種した結果, 実際に 発病が認められた。レタス腐敗病の病原細菌の一種で ある Pseudomonas cichorii は, 乾燥罹病葉を土壌中に 埋没した場合 6 力月間の生存が確認されている11。し かし，本試験では罹病小葉を非殺菌土壤中に埋没した 場合，土壤表面や実験室内に放置した場合に比べ，䍜 病小葉の腐朽が速いことから, 土壤中の各種微生物に より葉肉組織が腐朽し，それにともない本病細菌が急 激に死隇したものと思われた。これと同様にXanthomonas campestris pv. citri は, 䍜病葉を土壌中に埋没す ると葉の腐朽とともに急速に死隇する12)が，イネワラ やシバに付着したものは, 乾燥条件では雑菌との共存 下でも長期間生存する3)。また, X.c.pv. glycines に罹 病したダイズ葉を深さ 15 あるいは $30 \mathrm{~cm}$ の地中に埋 めた場合は 3 カ月しか生存しなかったが，地表面に置 いた場合は7 カ月の生存が確認されている2)。本病細 菌の場合も, 罹病小葉中での生存菌数は小葉の腐朽の 進行とともに減少するものと思われるが，地表面に存 在する罹病小葉中には, コンニャクの植付け時期で ある翌年の 4 5 月でも本病細菌が生存して和り， か つ, 実際に伝染源として発病をもたらす能力を有して いた。したがって，地表面に残存する罹病小葉は本病 の伝染源になることが明らかになった。

コンニャクの球茎上に特ける本病細菌の生存期間に ついて調査した結果, $10 \mathrm{C}$ のコンニャク種球専用貯 蔵庫内区と屋外土壤中埋没区で, コンニャクの植付 け時期である 4 月までは本病細菌の球茎上での生存が 確認され, さらに, 両処理区の球茥を 5 月に殺菌土堙 に植え付けた結果, その後伸長した株の小葉に発病が
認められた。一方， $25 \mathrm{C}$ の実験室内および屋外地表 面放置区は，4 月には本病細菌の検出がなく, $25 \mathrm{C}$ の 実験室内放置区の球茎を殺菌土壇に植光付けた結果で も発病が認められなかった。したがって，本病細菌は 高温条件下で菌数の減少が速く, 生存には $25 \mathrm{C}$ より も $10 \mathrm{C}$ 前後の方が適していると思われた。また，地 表面に放置された球茎は，冬期間に凍害を受け，4 月 の時点ですべてが腐敗・枯死したが, 土堙中に埋没し た球茎は大部分が球茎の腐敗もなく, 主芽も貯蔵開始 時と同様な状態を維持していた。すなわち，土壤中に 埋没された球茎は外気温の影響を受けにくいため, 貯 蔵開始時々同様な状態で越冬が可能であり，球茎表面 に特ける腐生的な微生物の増殖が少なく, 本病細菌の 生存にも好条件となったものと思われた。それに対し て地表面に放置された球茎は，凍害に起因する腐敗の 進行とともに生存本病細菌数が減少したものと思われ た。

土壤に灌注された本病細菌は, 非殺菌土壤中では急 激に密度が低下し，とくに高温条件下で速やかであっ た。一方, 殺菌土壤の場合は菌密度低下の速度が遅か った。P.s. pv. lachrymans あるいは, P.s. pv. tabaci は土壌に灌注された場合，いずれも殺菌土堙に比べ非 殺菌土壌で菌密度の低下が速いことが確認されてい る9,10)。したがって, 自然条件下では, コンニャクの 球茎や小葉等の組織を離れた土壌中の本病細菌は, 翌 年の伝染源になる可能性は少ないと思われた。

以上の結果から, 宿主組織から離れて土畩中に存在 する本病細菌は，次作の伝染源となる可能性は低い が，地表面に残存する罹病小葉残渣拉よびュンニャク 貯蔵庫内の種球あるいは収穫時に掘り残された土壇中 の球茎上に存在する本病細菌は, 次作の伝染源になる 可能性があると推定された。

\section{摘 要}

Pseudomonas pseudoalcaligenes subsp. konjaci によ るコンニャク葉枯病の伝染源を明らかにするため, 罹 病小葉組織内, 球茎上特よび土畩中に紋ける病原細菌 の生存期間を本病細菌検出用選択培地を用いて検討し た。9月に罹病小葉を非殺菌土壤中に埋没した場合 は，処理後 106 日以降には病原細菌が検出できなかっ たが，殺菌土壤に埋没した場合は処理後 244 日でる検 出された。一方, 屋外の地表面あるいは実験室内に置 いた場合は，処理後 422 日まで本病細菌が検出され た。また, 罹病小葉を 12 月から翌年 5 月まで固場地 表面に放置した罹病小葉残渣を, 本病未発生圃場の種 
球植付け直後の地表面に接種した結果, これが伝染源 となって本病が発生したことを確認した。球茎を 11 月に本病細菌液に浸漬接種したのち, $10 \mathrm{C}$ のコンニャ ク種球専用貯蔵庫および屋外土塞中(地表下 $10 \mathrm{~cm}$ ) に 保存した場合は翌年の 4 月でも本病細菌が検出された が，25 C の室内抽よび屋外の地表面に放置した場合 は, 翌年の 1 月まで本病細菌を検出したものの, それ
以降は検出されなかった。土壌中に灌注された本病細 菌は, $25 \mathrm{C}$ に比べ $5 \mathrm{C}$ で生存期間が長かったが, 非殺 菌土壤中では $5 \mathrm{C}$ でも接種 60 日目には検出されなか った。以上の実験結果から，地表面使存する羅病小 葉残渣中およびコンニャク種球専用貯蔵庫内 $(10 \mathrm{C})$ あ るいは土壤中の球茎上に存在する本病細菌は, 次作の 伝染源になる可能性があると推定された。

\section{引用 文 献}

1. 新井吾郎・山賀一郎・五味美知男 (1975). コンニャク栽培の新技術. 群馬県農業改良協会, 前橋. pp. 161-246.

2. Fett, W.F. (1979). Plant Dis. Rep. 63: 79-83.

3. 後藤正夫・太田光輝・岡部徳夫 (1975). 日植病報 $41: 141-147$.

4. Goto, M. (1983). Int. J. Syst. Bacteriol. 33: 539-545.

5. 林 宣夫 (1987). 日植病報 $53: 489-494$.

6. 平田栄吉 (1927). 農事試報 $48: 1-45$.

7. 鋳方末彦 (1935). 農及園 $10: 1695-1702$.

8. 西山幸司・江塚昭典 (1977). 日植病報 $43: 426-431$.

9. 小川 奎・駒田 旦・竹内昭士郎 (1981). 農事試研報 $35: 155-177$.

10. 小野邦明 (1976)。盛岡たばこ試報 $11: 1-52$.

11. 大畑貫一・芹沢拙夫 ・白田 昭 (1982). 農技研報 C 36:75-80.

12. Peltier, G.L. and Frederich, W.J. (1926). Jour. Agr. Res. 32: 335-345.

13. 上田栄次郎 (1910). 植物学雑誌 24 (281) : 177-182.

14. 若林重道 (1957). 最新コンニャク栽培と加工. 産業図畫, 東京. pp. 128-130.

15. 山本 勉. 川尻啓介 (1967). 四国植物防疫研究 2:61-72.

16. 山本 勉. 川尻啓介 (1967). 徳島農試報 $9: 27-33$. 